\title{
Activity of Lymphocyte Subpopulations in Polymicrobial Sepsis and DHEA Treatment in IL-6 Knockout Mice
}

\author{
Christian Zeckey $^{\mathrm{a}}$ Frank Hildebrand $^{\mathrm{a}}$ Petra Hoevel $^{\mathrm{b}}$ Kathrin Müller ${ }^{\mathrm{b}}$ \\ Christian Krettek $^{\mathrm{a}}$ Tanja Barkhausen $^{\mathrm{b}}$ Martijn van Griensven ${ }^{\mathrm{a}-\mathrm{c}}$ \\ a Trauma Department and bexperimental Trauma Surgery, Hannover Medical School, Hannover, Germany; \\ 'Ludwig Boltzmann Institute for Experimental and Clinical Traumatology, Vienna, Austria
}

\section{Key Words}

Dehydroepiandrosterone $\cdot$ Sepsis $\cdot$ Lymphocyte

subpopulations $\cdot$ Interleukin $6 \cdot$ Immunomodulation •

Shock $\cdot$ Natural killer cells $\cdot \mathrm{CD} 8^{+}$cells

\begin{abstract}
Introduction: Sepsis with subsequent multiorgan dysfunction remains the leading cause of mortality in trauma patients. A gender dimorphism in the host response after trauma and sepsis has been revealed. Dehydroepiandrosterone (DHEA), one of the most abundant adrenal sexual steroid hormones, seems to have a protective immunological effect in sepsis. Knowledge of the pathway is sparse; however, a cellular modulation mediated by interleukin-6 (IL-6) has been proposed. Materials and Methods: The effect of DHEA on survival, clinical parameters and the cellular immune system ( $T$ lymphocytes and NK cells) was examined in a model of polymicrobial sepsis induced by cecal ligation and puncture. For clarification of the role of IL- 6 in the protective effect of DHEA, we used IL-6 knockout mice (IL-6-/-). As controls, experiments were performed on wild-type mice (WT). $\boldsymbol{R e}$ sults: The administration of DHEA in IL- $6^{-/}$mice did not affect mortality, as it was not significantly different from WT mice without DHEA application. The cellular immune re-
\end{abstract}

sponse was influenced, as seen by a significant reduction in the percentage of $\mathrm{CD}^{+}$and NK cells in WT animals. Conclusions: Mortality rates in IL- $6^{-/-}$mouse strains were not lowered by DHEA; therefore, a limited effect of IL- 6 on this pathway has to be proposed. NK cells may be one of the effector cells of the protective mechanisms of DHEA, whilst the role of $\mathrm{CD}^{+}$lymphocytes remains unclear. Consequently, DHEA might be presented as a possible adjuvant therapy after septic insult for modulation of the dysregulated immune system.

Copyright @ 2010 S. Karger AG, Basel

\section{Introduction}

Sepsis is known to be associated with a variety of immunological modifications. T-cell-dependent immunity was markedly depressed after induction of polymicrobial sepsis in a rodent model [1]. For $\mathrm{Th}_{1}$ cells, a significantly reduced synthesis of IL-2 and a decreased expression of IL-2 receptors was observed in septic patients $[2,3]$. As IL- 2 acts as an autocrine stimulator of $\mathrm{Th}_{1}$ cells and leads to the activation of $\mathrm{CD}^{+}$and $\mathrm{CD} 56^{+}$lymphocytes, a general decrease in $\mathrm{T}$ cell proliferation has been described in these patients $[4,5]$. Moreover, apoptosis of T cells during septic shock has been described, leading to a cellular im-

\section{KARGER \\ Fax +4161306 1234 \\ E-Mail karger@karger.ch}

www.karger.com (c) 2010 S. Karger AG, Basel

$1662-811 X / 10 / 0025-0469 \$ 26.00 / 0$

Accessible online at:

www.karger.com/jin
Prof. Martijn van Griensven

Ludwig Boltzmann Institute for Experimental and Clinical Traumatology

Donaueschingenstrasse 13, AT-1200 Vienna (Austria)

Tel. +4313311 0793, Fax +43133110460

E-Mail Martijn.van.Griensven@trauma.lbg.ac.at 
mune defect. Recent research demonstrated that apoptosis of T cells is associated with poor outcome in patients with septic shock $[6,7]$.

Beside lymphocytes, NK cells also play a critical role in the development of systemic inflammation after trauma and sepsis [8]. Depletion of NK cells has been shown to improve survival in hemorrhage and sepsis models [9, 10].

According to experimental and clinical studies, increased IL- 6 concentrations seem to play an important role in the pathogenesis of sepsis by exerting pro- and anti-inflammatory effects $[10,11]$. IL- 6 has been shown to be one of the most reliable parameters to assess both the severity of sepsis and the outcome of septic patients $[11,12]$.

Recent investigations have described an association between these immunological alterations and disturbances of the endocrine system, mostly sex steroid hormones. Increased concentrations of circulating cytokines lead to an activation of the endocrine system. It can therefore be proposed that the immunologic response can be influenced by therapy directed towards the hormonal dysregulation [13-15]. Dehydroepiandrosterone (DHEA; 5 -androsten-3-ol-17-one) is one of the most abundant adrenal sex steroid hormone precursors in adult men and women [16]. In general, DHEA has been shown to improve cellular immune function in various sepsis and hemorrhage models [17-23] by differently affecting an increased synthesis of pro-inflammatory mediators (IFN- $\gamma$, IL-2, IL-6), as well as a decreased production of anti-inflammatory parameters (IL-4, IL-10) [24-26]. Furthermore, a significantly reduced expression of adhesion molecules on the surface of neutrophils and endothelial cells accompanied by decreased tissue infiltration of neutrophils has been demonstrated after a septic insult $[17-19,21,22]$. In healthy volunteers, DHEA application was associated with alterations in subsets of T lymphocytes. A reduction in blood levels of $\mathrm{CD} 4^{+}$and an increase in the concentrations of $\mathrm{CD} 8^{+}$and $\mathrm{CD} 56^{+}$cells following administration of DHEA have been described [23].

It is currently unknown how DHEA influences the interaction between the crosstalk of the humoral and cellular immune system. In this study, we hypothesized that the protective effects of DHEA treatment on the immune function in a septic situation are mainly mediated by IL6. Therefore, IL-6 knockout (IL- $6^{-/-}$) mice were observed in a polymicrobial sepsis model with regard to the survival rate, the clinical status, the delayed type of hypersensitivity reaction (DTH reaction) and the expression of lymphocyte subpopulations $\left(\mathrm{CD} 4^{+}, \mathrm{CD}^{+}\right.$and $\left.\mathrm{CD} 56^{+}\right)$.

\section{Material and Methods}

Animals

The experiments were performed on 57 male C57Bl/6 IL-6 ${ }^{-/-}$ mice aged 8-10 weeks and weighing $20 \pm 3$ g. As controls, wildtype (WT) male C57Bl/6 mice of similar weight were used $(\mathrm{n}=$ 40).

The animals were bred and raised in the central animal laboratory of the Hanover Medical School. Animals were maintained under standardized conditions in a controlled environment at $20 \pm 2{ }^{\circ} \mathrm{C}$, relative humidity of $50 \%$ and artificial light $(12 \mathrm{~h} \mathrm{light}$, $12 \mathrm{~h}$ darkness). They received a commercial pellet diet (altromin 1317) and water ad libitum. The study was approved by the animal welfare committee of the state of Lower Saxony.

\section{Cecal Ligation and Puncture}

After deeply anaesthetizing the animals with ketamine (100 $\mathrm{mg} / \mathrm{kg}$ ) and xylazine (16 mg/kg) s.c., polymicrobial sepsis was induced by cecal ligation and puncture (CLP). The cecum was exposed after a midline laparotomy, and unilateral puncture using an 18-gauge needle was performed twice. The model also includes the protrusion of the contents of the cecum to ensure the presence of bacteria in the peritoneum. Finally, the closure of the abdomen was performed with double-layer sutures.

\section{Experimental Groups}

Four different groups were included in the experimental design. As a control, sham operations with only a laparotomy were performed in 2 groups. Two other groups were subjected to CLP. One group of the sham-operated animals and 1 group of the CLP animals received DHEA ( $25 \mathrm{mg} / \mathrm{kg}$ s.c.) immediately after the operation (sham or CLP) and once daily (24, 48 and $72 \mathrm{~h}$ after the operation) thereafter. Mice of the 2 remaining groups received subcutaneous saline infusions of normal saline including $0.1 \%$ ethanol, while groups treated with DHEA received this substance dissolved in normal saline; thus, resulting in equal quantities of fluid as the saline groups. The ethanol content of the DHEA solution in saline amounted to $0.1 \%$. This is important as ethanol as such can modulate the immune response. In the sham animals, a laparotomy and subsequent injections of normal saline were applied without DHEA injections. In sham groups with DHEA application, a sham laparotomy was followed by a DHEA application. The mice were warmed to $36^{\circ} \mathrm{C}$ using warming lamps after the surgical procedure. The 4 experimental approaches were each carried out on WT animals and IL- $6^{-/-}$mice (fig. 1; table 1).

\section{Blood Collection}

Animals were killed $96 \mathrm{~h}$ after CLP or sham operation. Once again, all animals were deeply anesthetized using ketamine and xylazine (100 and $16 \mathrm{mg} / \mathrm{kg}$, respectively). The animals were fixed in a supine position. They were exsanguinated by cardiac puncture. Early clotting of the blood was avoided by heparin (Hoffmann-La Roche, Grenzach-Wyhlen, Germany). Blood was centrifuged for $5 \mathrm{~min}$ at $13,000 \mathrm{~g}$. The cellular components of blood were re-suspended with $1 \mathrm{ml}$ saline $(0.9 \%)$. After that, the determination of $\mathrm{CD}^{+}, \mathrm{CD}^{+}$and NK cells was performed.

\section{Clinical Parameters}

Body temperature, weight and mortality were determined $48 \mathrm{~h}$ prior to as well as $12,24,48,72,84$ and $96 \mathrm{~h}$ after the opera- 
Fig. 1. Time course of the experiments. DNFB = Dinitrofluorobenzene.

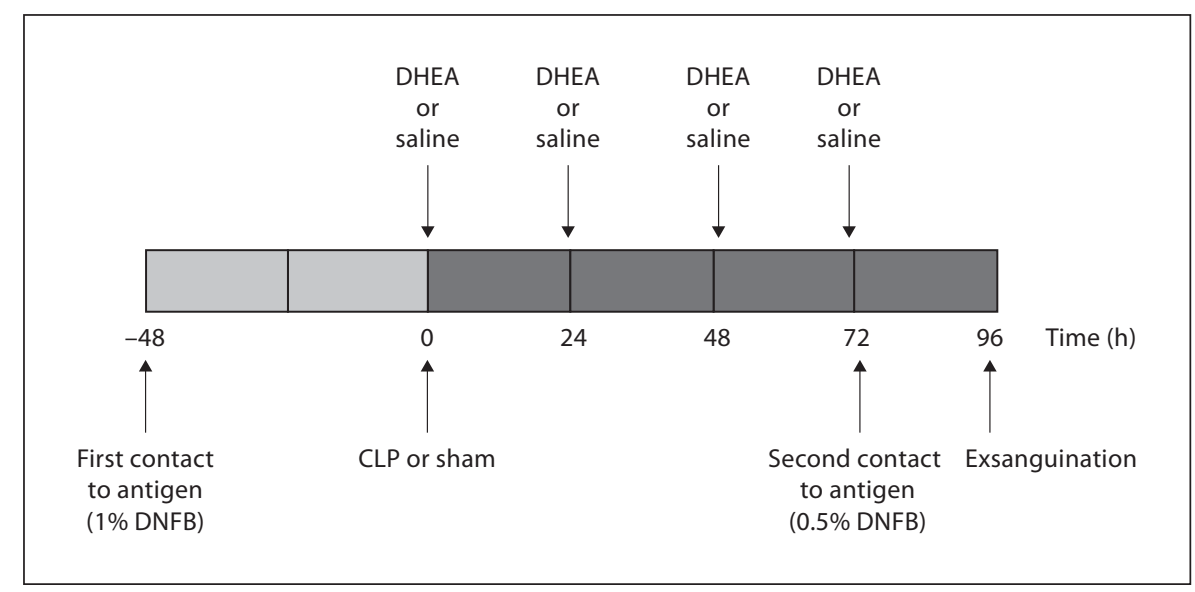

Table 1. Distribution of animals in experimental groups (n)

\begin{tabular}{llll}
\hline & & WT & IL-6 $^{-/-}$ \\
\hline \multirow{2}{*}{ Sham } & saline & 10 & 10 \\
& DHEA & 10 & 10 \\
\hline CLP & saline & 11 & 21 \\
& DHEA & 9 & 16 \\
\hline
\end{tabular}

tion. Measurement of the temperature was performed rectally with a digital thermometer (Greisinger Electronic, Bonn, Germany).

Body weight was determined on a scale. The differences in the respective body weights $(12,24,48,72,84,96 \mathrm{~h})$ were calculated in reference to the body weight at the time of the operation (0 h).

\section{Phenotyping by Flow Cytometry}

Erythrocytes in the blood samples were lysed using a solution containing $8.3 \mathrm{~g} \mathrm{NH}_{4} \mathrm{Cl}, 0.1 \mathrm{~g}$ EDTA and $1.0 \mathrm{~g} \mathrm{KHCO}_{3}$ dissolved in 1 liter distilled water for $10 \mathrm{~min}$. After washing twice with PBS, the leukocyte fraction was dissolved in PBS ( $\mathrm{pH} 7.4$ ); $100 \mu$ l of the suspension was added to $5 \mu \mathrm{g}$ of each antibody in different polypropylene tubes. Antigens detected were CD4, CD8 and CD56 (Ly49c as a mouse equivalent, Pharmingen, Freiburg, Germany). The CD4-FITC and CD8-PE antibodies were applied in one tube in order to detect $\mathrm{CD} 4^{+}$and $\mathrm{CD}^{+}$populations. Cells were incubated with the antibodies at $4^{\circ} \mathrm{C}$ for $20 \mathrm{~min}$. After washing twice with PBS, cells were re-suspended in binding buffer and measured immediately. Measurements were performed using a FACSCalibur cytometer (Becton Dickson, Heidelberg, Germany). A sample free of antibodies was used as negative control to adjust forward and sideward scatter and the fluorescence channels. A sample with an irrelevant anti-mouse antibody was used to check for non-specific staining effects. Five thousand lymphocytes per sample were counted using gating for lymphocytes. The gate was set using the negative control. By means of WinMDI software, the relative amounts of lymphocytes subsets were determined.

\section{DTH Reaction}

The DTH reaction (type IV reaction) was measured by the degree of pinna swelling, determined after local sensitization with dinitrofluorobenzene (DNFB, Sigma-Aldrich, Deisenhofen, Germany). Baseline values of pinna thickness were measured from the right pinna using an engineering micrometer (Oditest, Kroeplin, Germany). DNFB was diluted in acetone and olive oil to concentrations of 0.5 and $1.0 \%$. The dorsal skin was shaved and $50 \mu \mathrm{l}$ DNFB (1.0\%) was applied $48 \mathrm{~h}$ before the operation. Mice were then challenged using $0.5 \%$ DNFB on the dorsal skin of the right pinna $72 \mathrm{~h}$ after CLP or sham operation. Pinna swelling was again measured $24 \mathrm{~h}$ later.

\section{Statistics}

Statistical analysis was performed using standard software (SPSS 9.0). Comparison between groups (CLP vs. sham; IL-6 $6^{-/-}$vs. WT; DHEA vs. saline) was performed using one-way ANOVA and a post hoc Tukey test. Survival was compared using a log rank test. A probability value less than 0.05 was considered statistically significant. All data are expressed as means \pm SEM.

\section{Results}

\section{Clinical Parameters}

\section{Survival Rates}

All sham-operated animals survived the experiment until exsanguination $96 \mathrm{~h}$ after laparotomy. In the group of WT-CLP-saline mice, 5 of 11 animals died. This corresponds to a mortality of $45.5 \%$. In the WT-CLP-DHEA group, 1 mouse out of 9 died, the mortality being only $11.1 \%(\mathrm{p}<0.05)$.

In the group of IL- $6^{-/-}$-CLP-saline mice, 10 out of 21 operated mice survived (mortality: 52.4\%). The administration of DHEA (IL- $6^{-/-}$-CLP-DHEA) was associated with a mortality of $62.5 \%$ (10 out of 16 operated mice died, $\mathrm{p}>0.05$; fig. 2). 
Body Weight

Postoperatively, all animals suffered an average weight loss of $1.4 \pm 0.1 \mathrm{~g}$ in the first $24 \mathrm{~h}$. Sham-operated animals increased their weight again, reaching their initial weight by the end of the experiment.

The CLP animals suffered a marked loss of weight $72 \mathrm{~h}$ after induction of sepsis.

The IL- $6^{-1-}$-CLP-saline mice showed significantly decreased body weight compared to WT animals $(\mathrm{p}<0.05)$ after 24 and $48 \mathrm{~h}$.

\section{Body Temperature}

The average body temperature of all animals was 35.9 $\pm 0.2^{\circ} \mathrm{C}$ before starting the experiments. Sham animals demonstrated a normal body temperature during the entire observation period. The body temperature of animals that underwent CLP with substitution of DHEA was lower $12 \mathrm{~h}$ after induction of sepsis compared to values before commencing the experiments, and was also lower compared to sham-operated animals at the same point in time $\left(32.5 \pm 0.6^{\circ} \mathrm{C}\right)$. After 24,48 and $72 \mathrm{~h}$, no differences between the respective CLP groups were observed. Also, no differences were found when compared with sham-operated animals. Ninety-six hours after CLP, the average body temperature of CLP mice dropped to 33.1 $\pm 0.4^{\circ} \mathrm{C}$, while the other 2 remaining groups remained at baseline values $(\mathrm{p}<0.05)$.

\section{Phenotyping of Lymphocytes}

CD4 ${ }^{+}$Lymphocytes

The administration of DHEA in IL- $6^{-/-}$groups led to a slight increase in the percentage of $\mathrm{CD}^{+}$cells compared to the corresponding saline groups. This effect is inverse when compared to WT mice where DHEA reduced the number of $\mathrm{CD} 4^{+} \mathrm{T}$ lymphocytes. Compared to the respective sham groups, IL-6 ${ }^{-/-}$CLP groups showed a significant increase in $\mathrm{CD} 4^{+}$lymphocytes $(4.5 \%$; $\mathrm{p}=0.03)$, independent of DHEA application. In total, levels of $\mathrm{CD} 4^{+}$ cells were slightly lower in all IL- $6^{-/-}$groups when compared to the respective WT groups. In addition, a statistically significant difference between the IL- $6^{-1-}$-shamsaline $(10.3 \pm 1 \%)$ and the IL- $6^{-1-}$-sham-DHEA group $(13.9 \pm 1.2 \%)$ was found ( $\mathrm{p}=0.03$; fig. 3,4$)$.

\section{CD8 ${ }^{+}$Lymphocytes}

WT-CLP groups showed significantly higher percentages of $\mathrm{CD}^{+}$cells than IL- $6^{-/-}-\mathrm{CLP}$ groups, independent of DHEA application. However, a significant reduction in $\mathrm{CD}^{+}$cells was found in the CLP-DHEA group when compared to the sham-operated animals $(\mathrm{p}<0.05)$. CLP

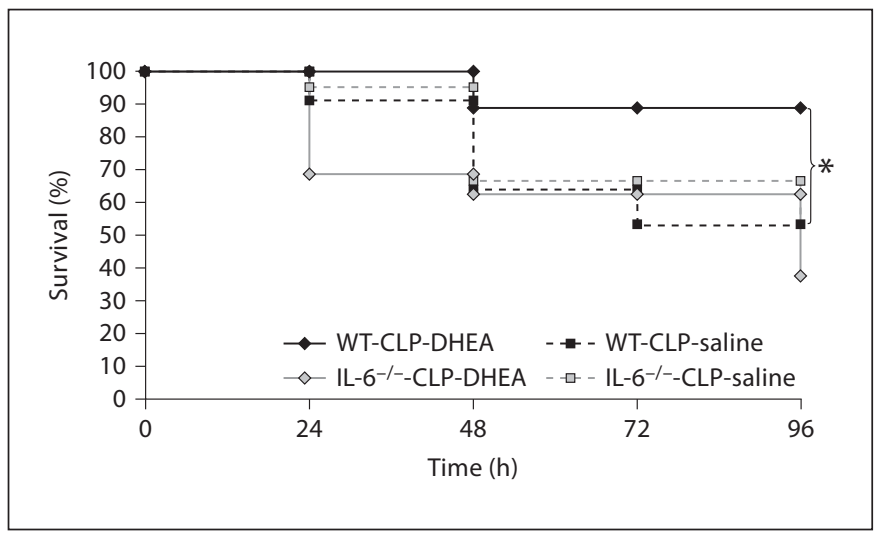

Fig. 2. Survival rates. There was a significant improvement in survival for the WT-CLP-DHEA group compared to WT-CLP-saline group. ${ }^{*} \mathrm{p}<0.05$.

had no effect on $\mathrm{CD}^{+}$cells in the IL- $6^{-/-}$groups. The induction of sepsis by CLP did not lead to an increase in the $\mathrm{CD}^{+}$percentage in IL- $6^{-/-}$mice, whilst WT animals showed significantly higher $\mathrm{CD} 8^{+}$levels. In total, IL-6 $6^{-/-}$ groups showed a smaller percentage of $\mathrm{CD} 8^{+}$cells (statistical significance between the respective WT and IL- $6^{-/-}$ groups, $\mathrm{p}<0.05$; fig. 5).

\section{NK Cells}

Sham-operated animals with DHEA medication showed a reduced percentage of NK cells. In the case of CLP, IL- $6^{-/-}$animals showed significantly lower levels of NK cells than WT animals (IL-6 ${ }^{-1-}$-CLP-saline $6.9 \pm$ $1.2 \%$ vs. WT-CLP-saline $49.5 \pm 0.7 \%, \mathrm{p}<0.05$; IL-6 ${ }^{-1-}$ CLP-DHEA $11.7 \pm 1.9 \%$ vs. WT-CLP-DHEA $22.4 \pm$ $0.8 \%, \mathrm{p}<0.05)$. CLP significant increased NK cell levels in the IL-6 $6^{-/-}$-CLP-DHEA group to $11.7 \pm 1.9 \%$. This increase was also significant when compared to the IL$6^{-/-}$-CLP-saline group ( $\mathrm{p}<0.05$; fig. 6$)$.

\section{DTH Reaction}

Significant edema was found in all animals. The average pinna thickness of all animals was $0.21 \pm 0.01 \mathrm{~mm}$ before commencing the experiments, i.e. $48 \mathrm{~h}$ before the operation. An increase in the average pinna thickness to $0.37 \pm 0.01 \mathrm{~mm}$ was observed $24 \mathrm{~h}$ after the second antigen contact in $\mathrm{IL}-6^{-/}$mice. This was significantly lower than in WT animals (WT: $0.53 \pm 0.01 \mathrm{~mm}$ ).

In the IL- $6^{-/-}$-sham-saline group, pinna swelling of $0.33 \pm 0.02 \mathrm{~mm}$ was found, while in the IL- $6^{-1-}$-shamDHEA group, this value was $0.38 \pm 0.02 \mathrm{~mm}(\mathrm{p}<0.05)$. In $\mathrm{IL}-6^{-/-}$mice, sepsis did not lead to a difference in 
Fig. 3. Percentage of $\mathrm{CD} 4^{+}$lymphocytes in blood of IL- $6^{-/-}$mice. The administration of DHEA in IL- $6^{-/-}$groups led to a slight increase in the percentage of $\mathrm{CD}^{+}$cells compared to the corresponding saline groups. IL- $6^{-/-}$-CLP groups showed, compared to the respective sham groups, a significant increase in $\mathrm{CD}^{+}$lymphocytes, independent of DHEA application. ${ }^{*} \mathrm{p}<$ 0.05 .

Fig. 4. Percentage part of $\mathrm{CD} 4^{+}$lymphocytes in blood of WT and IL- 6 knockout (IL-6 $6^{-/-}$) mice. In total, in all $\mathrm{IL}_{-} 6^{-/-}$ groups, levels of $\mathrm{CD}^{+}$cells were slightly lower compared to the respective WT groups. ${ }^{*} \mathrm{p}<0.05$.

Fig. 5. Percentage part of $\mathrm{CD} 8^{+}$lymphocytes in blood of WT and IL- $6^{-1-}$ mice. WT-CLP groups showed significantly higher percentages of $\mathrm{CD}^{+}$cells than IL$6^{-1-}$-CLP groups, independent of DHEA application. CLP had no effect on $\mathrm{CD}^{+}$ cells in IL- $6^{-1-}$ groups. The induction of sepsis by CLP did not lead to an increase in $\mathrm{CD} 8^{+}$percentage in IL- $6^{-/-}$mice, whereas WT animals showed significantly higher CD8 ${ }^{+}$levels. ${ }^{*} \mathrm{p}<0.05$.
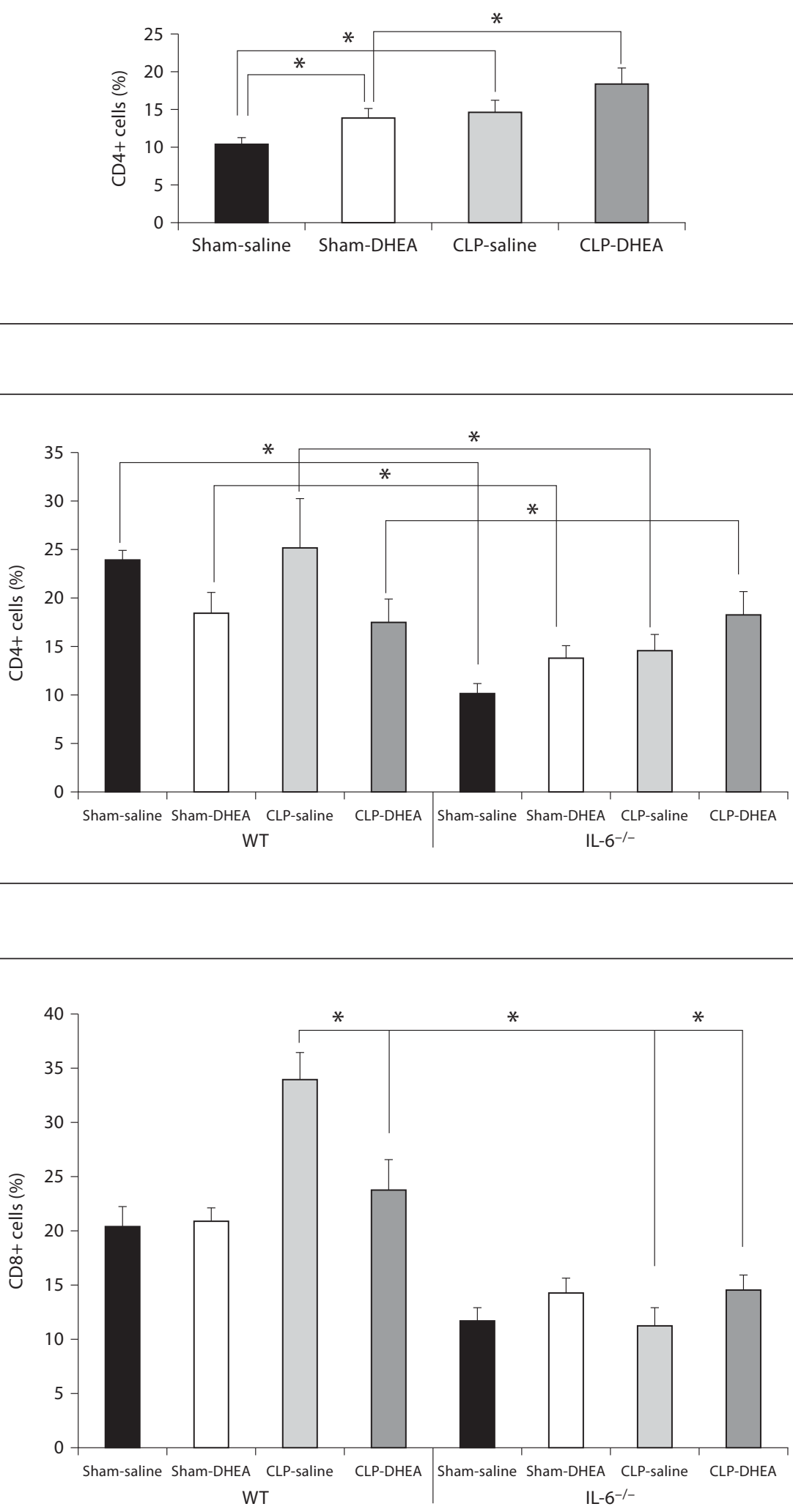

J Innate Immun 2010;2:469-477 
Fig. 6. Percentage part of $\mathrm{CD}^{+} 6^{+}(\mathrm{NK})$ lymphocytes in blood of WT and IL- $6^{-/-}$ mice. Sham-operated animals with DHEA medication showed a reduced percentage of NK cells. In case of CLP, IL- $6^{-/-}$animals showed significantly lower levels of NK cells than WT animals. CLP caused a significant increase in NK cell levels in the IL- $6^{-1-}$-CLP-DHEA group. This increase was also significant compared to the IL$6^{-/-}$-CLP-saline group. ${ }^{*} \mathrm{p}<0.05$.

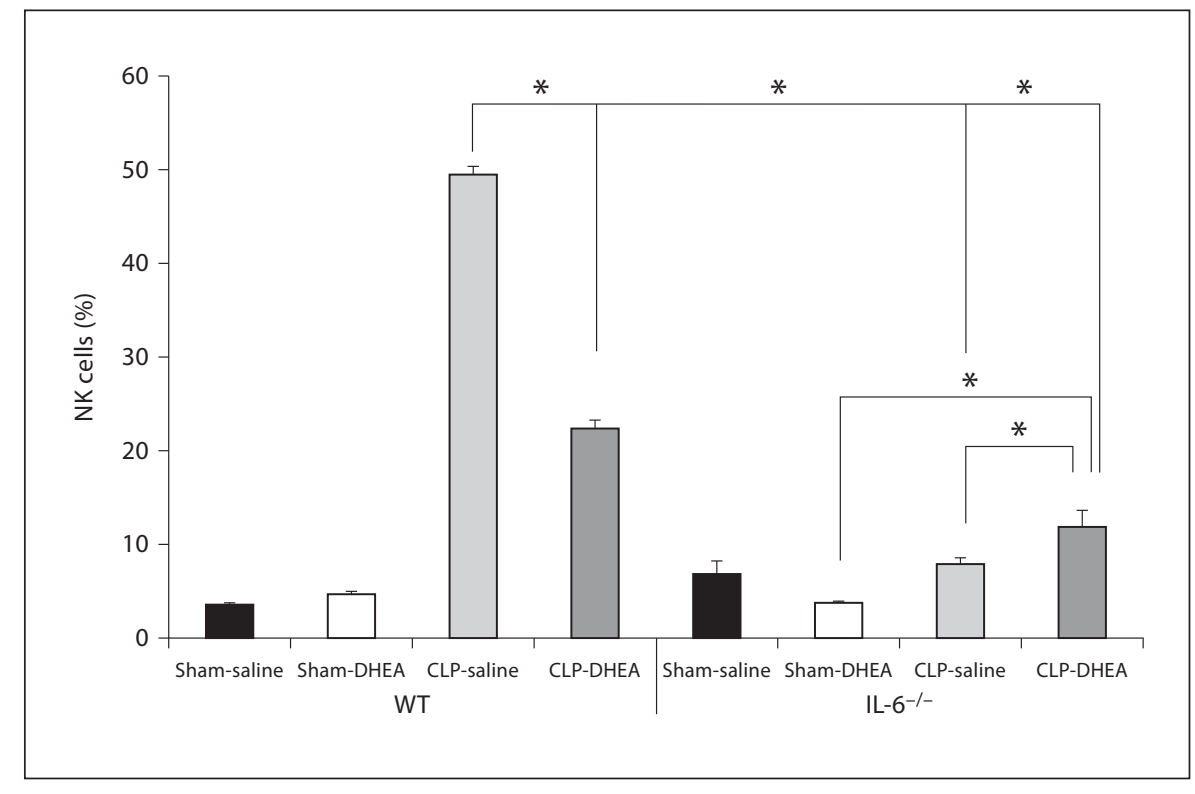

DTH reaction $\left(\mathrm{IL}-6^{-/-}\right.$-CLP-saline $0.36 \pm 0.03 \mathrm{~mm}$ and IL-6 ${ }^{-1-}$-CLP-DHEA $0.40 \pm 0.05 \mathrm{~mm}$; p $>0.05$ vs. IL$6^{-/-}$-sham-saline). In CLP groups, the differences in ear thickness after DHEA treatment were not statistically significant (fig. 7, 8).

\section{Discussion}

In the present study, we wanted to reveal the influence of DHEA on subpopulations of lymphocytes in WT and IL- $6^{-/-}$mice in a CLP model. Furthermore, we wanted to assess possible target cells of DHEA and clarify the role of IL-6 in DHEA treatment.

According to the results of our study, DHEA seems to have a significant effect on $\mathrm{CD}^{+}$and NK cells. The application of DHEA led to a significant increase in the percentage of $\mathrm{CD}^{+}$and NK cells in the knockout animals, whereas this was significantly decreased in WT animals. No effects of DHEA were found in the corresponding sham-operated animals. Effects of DHEA on the percentage of $\mathrm{CD}^{+}$were not found, and no positive effects towards survival were achieved by DHEA in IL- $6^{-1-}$ mice. In the present setting, we therefore conclude that $\mathrm{CD}^{+}$ and NK cells seem to be possible effector cells of DHEA, and that part of the beneficial effect of DHEA is mediated via IL-6.

In our study, we were able to demonstrate the profound influence of DHEA. One of the most important and nov- el findings of our study is that septic WT mice treated by DHEA showed a significantly decreased amount of NK cells in the peripheral blood. This corresponds to the improved survival of WT mice in comparison to the saline group. These findings are in line with our recently published study [17]. In this series of a combined traumahemorrhage (femur fracture and volume-controlled hemorrhage) and sepsis model, we could demonstrate the beneficial effects of antibody-depleted NK cells in septic mice. We found not only improved survival rates, but also reductions in the inflammatory response and a decrease in infiltrating neutrophils in the lung. Furthermore, decreased lymphocyte apoptosis in the spleen was revealed [17]. The critical role of NK cells under septic conditions is also supported by other recent studies. Carson et al. [18] revealed the role of NK cells in a septic shock model induced by IL-2 and IL-12. All animals with detectable NK cells died during the observation period; the investigators found protection in mice with congenital absence or depletion of NK cells. In a further study by Badgwell et al. [9], the mortality following depletion of NK cells in mice receiving an intraperitoneal bacterial challenge was significantly enhanced. NK-depleted and NK-deficient mice exhibited a significantly improved survival compared to controls. In this setting, the serum levels of pro-inflammatory cytokines were markedly reduced; furthermore, obvious changes in the histology of the kidney and the lung could be observed in the control animals. 


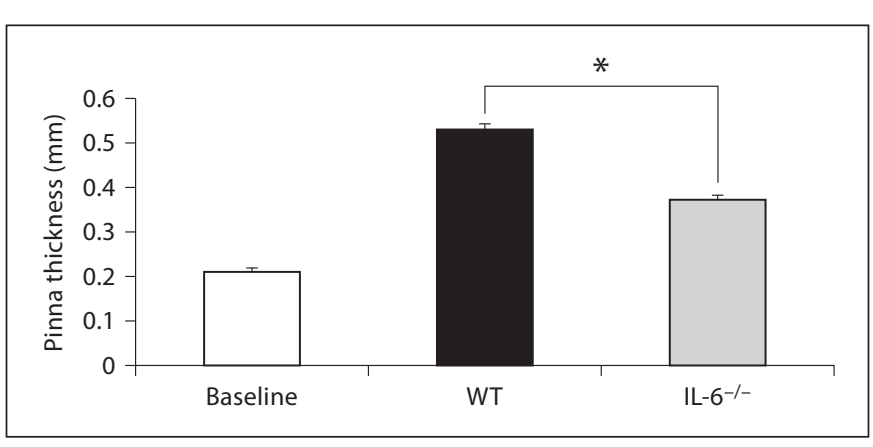

Fig. 7. DTH reaction. An increase in the average pinna thickness was observed $24 \mathrm{~h}$ after the second antigen contact in IL- $6^{-/-}$mice. This was significantly lower than in WT animals. ${ }^{*} \mathrm{p}<0.05$.
In our study, we could demonstrate decreased $\mathrm{CD} 4^{+}$ levels in WT animals following CLP and DHEA treatment. However, this reduction was not statistically significant. In contrast, the percentage of $\mathrm{CD}^{+}$cells following CLP and DHEA treatment was significantly increased in IL- $6^{-/-}$animals, but still lower than in WT animals. This might be explained by a partial IL-6-mediated effect of DHEA.

The depletion of $\mathrm{CD}^{+}$cells in septic conditions has been described in recent studies. One of the main findings in these studies is the decrease in $\mathrm{CD} 4^{+}$cells during the overwhelming immune status of the patients [22]. Apoptosis of $\mathrm{CD}^{+}$cells is another important finding in recent septic research. Due to the loss of lymphocytes, depression of the immune system can be observed. Moreover, not only the loss of cells leads to a depression, an immunosuppressive effect of apoptotic cells could also be demonstrated in recent studies [21].

In our study, DHEA led to a significant increase in $\mathrm{CD}^{+}$cells in $\mathrm{IL}_{-} 6^{-/-}$animals. The percentage of these cells in the corresponding WT animals decreased. The role of $\mathrm{CD}^{+}$cells in the septic setting is not fully understood. As known from clinical use in HIV and HCV infections and therapy, $\mathrm{CD}^{+}$cells play an essential role in the control of intracellular infections [19]. As the CD8 ${ }^{+}$ cells are a reasonable source of IFN- $\gamma$ and TNF- $\alpha$ in septic conditions [20], it might be suggested that DHEA could exert beneficial effects in this setting. Therefore, reduced TNF- $\alpha$ might in part be a result of the depleted $\mathrm{CD} 8^{+}$cells.

These results were accompanied by a marginal response in the DTH reaction. The DTH reaction, usually depressed following CLP as sign of a compromised type IV hypersensitivity, is a widely accepted method for the

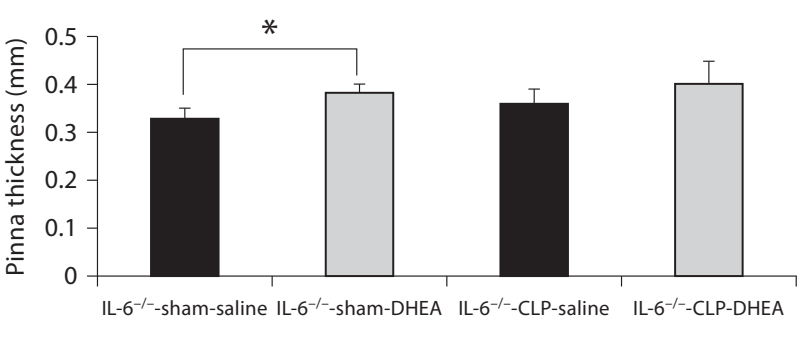

Fig. 8. DTH reaction. A significant increase in the average pinna thickness was observed in the IL- $6^{-/-}$-sham-DHEA group compared to the IL- $6^{-/-}$-sham-saline group. In IL- $6^{-/-}$mice, sepsis did not lead to a difference in DTH reaction.

determination of a T-cell-dependent immune reaction [23]. In our study, we were able to demonstrate slightly (but significantly) lower levels of edema in the IL- $6^{-/}$ mice. Furthermore, a slightly increased pinna swelling was found in the IL- $6^{-/-}$-sham-DHEA group in comparison to the IL- $6^{-/-}$-sham group. Therefore, we once again conclude that some of the beneficial effects of DHEA are mediated via IL-6.

The endocrine system is able to regulate the immune system. A recent study was able to demonstrate that up to $60 \%$ of female mice survived a polymicrobial sepsis, compared to only $25 \%$ of the male animals [14]. The higher survival rates of the female animals were associated with a higher proliferation rate of the splenocytes and increased IL-2 and IL-3 secretion. [13]. In contrast to male sex hormones, an improved immune response after application of female sex hormones in male animals was described [27]. In various studies, DHEA as an adrenal sex steroid hormone precursor has been shown to improve the cellular immune function [17-23].

In our study, no differences in body temperature courses or body weight curves were found in IL- $6^{-/-}$animals when compared to WT animals. This is in contrast to other reports that discussed IL-6 as a possible endogenous pyrogen. Chai et al. [28] reported that no fever developed in IL- $6^{-/-}$animals after application of lipopolysaccharide. Leon et al. [29] even observed a transient hypothermia during CLP in IL- $6^{-/-}$mice. They also found no differences in body weight between IL- $6^{-/-}$and WT mice, although IL- $6^{-/-}$animals had to undergo an extended duration of anorexia. The lack of a temperature drop in our study could be due to the heating lamps used. The role of IL- 6 in the pathogenesis of sepsis is still controversial. Many studies engage the pro-inflammatory 
role of IL- 6 in sepsis. Both a proliferation of B lymphocytes, which leads to an increased synthesis of immunoglobulin, and a proliferation of $\mathrm{T}$ lymphocytes are mediated by IL-6. Furthermore, IL- 6 causes an increased differentiation of cytotoxic $T$ cells and increases the activity of NK cells. However, some studies indicate that IL-6 might also have anti-inflammatory effects [30-32].

\section{Conclusion}

In a 50\% lethal model of CLP-induced polymicrobial sepsis, we were able to demonstrate significant effects of DHEA on $\mathrm{CD}^{+}$and NK cells. NK cells seemed to repre- sent possible effector cells of DHEA and were associated with improved survival. No beneficial effects on mortality in IL- $6^{-/}$mouse strains were found; therefore, a limited effect of IL- 6 in this pathway has to be proposed. DHEA appears to be one possible agent for an adjuvant therapy after sepsis because of its mortality-reducing effect by modulation of the dysregulated immune system.

\section{Acknowledgment}

The authors gratefully thank Mrs. Penelope Stiefel for her critical comments and didactical support.

\section{References}

1 Oberbeck R, Dahlweid M, Koch R, van Griensven M, Emmendorfer A, Tscherne H, Pape HC: Dehydroepiandrosterone decreases mortality rate and improves cellular immune function during polymicrobial sepsis. Crit Care Med 2001;29:380-384.

$\checkmark 2$ Gadd MA, Hansbrough JF, Hoyt DB, Ozkan $\mathrm{N}$ : Defective T-cell surface antigen expression after mitogen stimulation: an index of lymphocyte dysfunction after controlled murine injury. Ann Surg 1989;209:112-118.

- 3 Hoyt DB, Ozkan AN, Hansbrough JF, Marshall L, vanBerkum-Clark M: Head injury: an immunologic deficit in T-cell activation. J Trauma 1990;30:759-766, discussion 766757.

4 Hildebrand F, Pape HC, Harwood P, Wittwer T, Krettek C, van Griensven M: Are alterations of lymphocyte subpopulations in polymicrobial sepsis and DHEA treatment mediated by the tumour necrosis factor (TNF)-alpha receptor (TNF-RI)? A study in TNF-RI (TNF-RI(-/-)) knock-out rodents. Clin Exp Immunol 2004;138:221-229.

5 Sayeed MM: Alterations in cell signaling and related effector functions in T lymphocytes in burn/trauma/septic injuries. Shock 1996 5:157-166.

-6 Roger PM, Hyvernat H, Breittmayer JP, Dunais B, Dellamonica J, Bernardin G, Bernard A: Enhanced T-cell apoptosis in human septic shock is associated with alteration of the costimulatory pathway. Eur J Clin Microbiol Infect Dis 2009;28:575-584.

-7 Le Tulzo Y, Pangault C, Gacouin A, Guilloux V, Tribut O, Amiot L, Tattevin P, Thomas R, Fauchet R, Drenou B: Early circulating lymphocyte apoptosis in human septic shock is associated with poor outcome. Shock 2002 18:487-494 $\checkmark 8$ Sherwood ER, Enoh VT, Murphey ED, Lin CY: Mice depleted of CD8+ T and NK cells are resistant to injury caused by cecal ligation and puncture. Lab Invest 2004;84:16551665.

-9 Badgwell B, Parihar R, Magro C, Dierksheide J, Russo T, Carson WE 3rd: Natural killer cells contribute to the lethality of a murine model of Escherichia coli infection. Surgery 2002;132:205-212.

10 Goldmann O, Chhatwal GS, Medina E: Contribution of natural killer cells to the pathogenesis of septic shock induced by streptococcus pyogenes in mice. J Infect Dis 2005; 191:1280-1286.

11 Pape HC, Remmers D, Grotz M, Schedel I, von Glinski S, Oberbeck R, Dahlweit M, Tscherne H: Levels of antibodies to endotoxin and cytokine release in patients with severe trauma: does posttraumatic dysergy contribute to organ failure? J Trauma 1999; 46:907-913.

12 Presterl E, Staudinger T, Pettermann M, Lassnigg A, Burgmann H, Winkler S, Frass $\mathrm{M}$, Graninger W: Cytokine profile and correlation to the APACHE III and MPM II scores in patients with sepsis. Am J Respir Crit Care Med 1997;156:825-832.

13 Kahlke V, Angele MK, Ayala A, Schwacha MG, Cioffi WG, Bland KI, Chaudry IH: Immune dysfunction following trauma-haemorrhage: influence of gender and age. Cytokine 2000;12:69-77.

-14 Zellweger R, Wichmann MW, Ayala A, Stein $\mathrm{S}$, DeMaso CM, Chaudry IH: Females in proestrus state maintain splenic immune functions and tolerate sepsis better than males. Crit Care Med 1997;25:106-110.

15 Hsieh YC, Frink M, Choudhry MA, Bland KI, Chaudry IH: Metabolic modulators following trauma sepsis: sex hormones. Crit Care Med 2007;35:S621-S629.
16 Okabe T, Haji M, Takayanagi R, Adachi M, Imasaki K, Kurimoto F, Watanabe T, Nawata $\mathrm{H}$ : Up-regulation of high-affinity dehydroepiandrosterone binding activity by dehydroepiandrosterone in activated human $\mathrm{T}$ lymphocytes. J Clin Endocrinol Metab 1995; 80:2993-2996.

17 Barkhausen T, Frerker C, Putz C, Pape HC, Krettek C, van Griensven M: Depletion of NK cells in a murine polytrauma model is associated with improved outcome and a modulation of the inflammatory response. Shock 2008;30:401-410.

- 18 Carson WE, Yu H, Dierksheide J, Pfeffer K, Bouchard P, Clark R, Durbin J, Baldwin AS, Peschon J, Johnson PR, Ku G, Baumann H, Caligiuri MA: A fatal cytokine-induced systemic inflammatory response reveals a critical role for NK cells. J Immunol 1999;162: 4943-4951.

19 D'Cruz LM, Rubinstein MP, Goldrath AW: Surviving the crash: Transitioning from effector to memory $\mathrm{CD}^{+} \mathrm{T}$ cell. Semin Immunol 2009;21:92-98.

20 Harty JT, Badovinac VP: Influence of effector molecules on the CD8(+) T cell response to infection. Curr Opin Immunol 2002;14: 360-365.

21 Hotchkiss RS, Osmon SB, Chang KC, Wagner TH, Coopersmith CM, Karl IE: Accelerated lymphocyte death in sepsis occurs by both the death receptor and mitochondrial pathways. J Immunol 2005;174:5110-5118.

22 Hotchkiss RS, Tinsley KW, Swanson PE, Schmieg RE Jr, Hui JJ, Chang KC, Osborne DF, Freeman BD, Cobb JP, Buchman TG, Karl IE: Sepsis-induced apoptosis causes progressive profound depletion of $\mathrm{B}$ and $\mathrm{CD} 4^{+} \mathrm{T}$ lymphocytes in humans. J Immunol 2001;166:6952-6963. 
23 van Griensven M, Dahlweid FM, Giannoudis PV, Wittwer T, Bottcher F, Breddin M, Pape HC: Dehydroepiandrosterone (DHEA) modulates the activity and the expression of lymphocyte subpopulations induced by cecal ligation and puncture. Shock2002;18:445-449.

-24 Catania RA, Angele MK, Ayala A, Cioffi WG, Bland KI, Chaudry IH: Dehydroepiandrosterone restores immune function following trauma-haemorrhage by a direct effect on T lymphocytes. Cytokine 1999;11: 443-450.

25 Araneo B, Daynes R: Dehydroepiandrosterone functions as more than an antiglucocorticoid in preserving immunocompetence after thermal injury. Endocrinology 1995; 136:393-401.
26 Schurr MJ, Fabian TC, Croce MA, Varnavas LE, Proctor KG: Dehydroepiandrosterone, an endogenous immune modulator, after traumatic shock. Shock 1997;7:55-59.

27 Knoferl MW, Angele MK, Catania RA, Diodato MD, Bland KI, Chaudry IH: Immunomodulatory effects of dehydroepiandrosterone in proestrus female mice after trauma-hemorrhage. J Appl Physiol 2003;95: 529-535.

28 Chai Z, Gatti S, Toniatti C, Poli V, Bartfai T: Interleukin (IL)- 6 gene expression in the central nervous system is necessary for fever response to lipopolysaccharide or IL-1 beta: a study on IL-6-deficient mice. J Exp Med 1996;183:311-316.

29 Leon LR, White AA, Kluger MJ: Role of IL-6 and TNF in thermoregulation and survival during sepsis in mice. Am J Physiol 1998; 275:R269-R277.
30 Casey LC, Balk RA, Bone RC: Plasma cytokine and endotoxin levels correlate with survival in patients with the sepsis syndrome. Ann Intern Med 1993;119:771-778.

31 Lundblad R, Ekstrom P, Giercksky KE: Pentoxifylline improves survival and reduces tumor necrosis factor, interleukin-6, and endothelin-1 in fulminant intra-abdominal sepsis in rats. Shock 1995;3:210-215.

32 Oberholzer A, Souza SM, Tschoeke SK, Oberholzer C, Abouhamze A, Pribble JP, Moldawer LL: Plasma cytokine measurements augment prognostic scores as indicators of outcome in patients with severe sepsis. Shock 2005;23:488-493. 